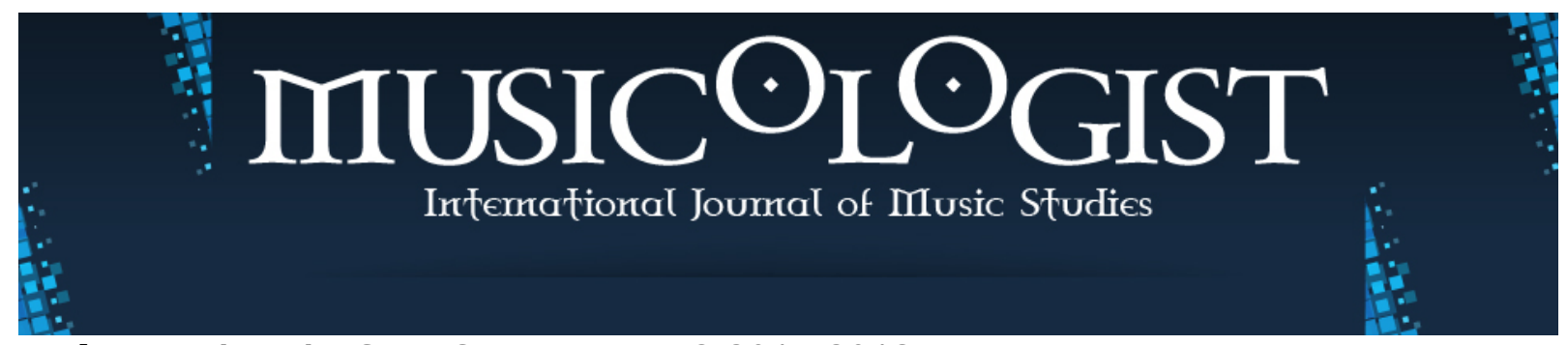

Trabzon University State Conservatory (c) 2017-2018

Volume 2 Issue 2 December 2018

Research Article

Musicologist 2018. 2 (2): 115-126

DOI: $10.33906 /$ musicologist.456708

NEVİN ŞAHİN (1)

Orient-Institut Istanbul, Turkey

nevinsahin@gmail.com

orcid.org/0000-0003-2604-0185
CENK GÜRAY (2)

Hacettepe University Ankara, Turkey

cenk.guray@gmail.com

orcid.org/0000-0002-9410-725X

ALİ FUAT AYDIN (3)

Music researcher, Turkey

alifuataydin@gmail.com

orcid.org/0000-0002-3299-8624

\title{
Cross-Cultural Influences in Makam Theory: The Case of Greek Orthodox Theorists in the Ottoman Empire
}

\section{ABSTRACT}

The makam theory, which has been transmitted for nearly 5,000 years in Anatolian culture through the periods of Ancient Greek, Roman, and Byzantine Empires, Medieval Islam, the Ottoman Empire, and the Turkish Republic, presents an efficient cultural base on which sociocultural changes can be traced. In this regard, the works of Greek Orthodox theorists, who played a dominant role in the transmission of Ottoman music theory, especially after the $17^{\text {th }}$ century, establish a powerful database for research on such topics as multi-culturalism in Ottoman music, the effect of Byzantine Music theory on Ottoman music, and the reflections of national identities in music. To be able to derive conclusions on these topics, the scope of this paper concentrates on a comparative survey of works of three Greek Orthodox theorists, namely Halaçoğlu, Marmarinos, and Kiltzanidis from the $18^{\text {th }}$ and $19^{\text {th }}$ centuries, and the works of other prominent theorists of the Ottoman music scene, such as Cantemir and Nâsır Abdülbâkî Dede. The comparative analysis provides a scope to better understand how the music related to the social life of the Ottoman Empire at the time, and how the aesthetic and social changes were reflected in the music.

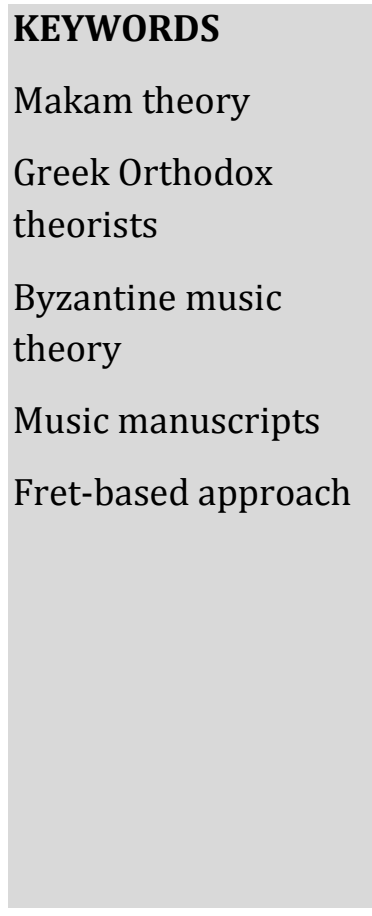




\section{Makam as a Tool for Cultural Cross-Sections ${ }^{1}$}

As the melody-organizing structures that make up the melodic patterns in traditional music mainly in Anatolia, Near East, and the Balkans, makam structures have been theorized for nearly 5000 years, going back to the Ancient Mesopotamian musical culture. Since then, the theory has been transmitted through a combination of memory and written manuscripts, establishing a cultural chain between the remains of the Ancient Greek, Roman, and Byzantine Empires, Medieval Islam, the Ottoman Empire and the Turkish Republic. Hence, makam theory, with its formulations, rules, and organizational logic defines one of the strongest tangible components of shared memory, shaped within these regions, enabling remarkable cross-sections of different historical periods.

Within the history of makam theory, the Ottoman Empire has a particular significance with its distinguishing cultural and artistic characteristics, through a multicultural dimension, which lies at the core of the cultural identity of the empire. The music scene of İstanbul is of special interest with regard to makam theory. Having become the capital of the Ottoman Empire once the Ottoman troops took over the city from the Byzantine Empire, İstanbul faced the development and the decline of the empire in social, cultural, and political senses. Throughout the historical process, İstanbul was home to quite a few important music theorists, many of whom authored manuscripts about makam music. Makam music was among the different music traditions that were alive in the daily life of İstanbulite citizens, who belonged to different ethnicities and religious origins. Within this multicultural context, the Greek Orthodox population represented a crucial point in the transmission process of Byzantine cultural heritage to the Ottoman culture.

This article aims to understand the music scene of İstanbul in the $18^{\text {th }}$ and $19^{\text {th }}$ centuries, in relation to the writing on makam music. The specific focus being on the Greek Orthodox theorists, this article digs into the interrelationship between the Byzantine cultural heritage and the Ottoman multicultural identity during the period

\footnotetext{
1 This article was developed from two conference presentations, by Cenk Güray and Ali Fuat Aydin at the $2^{\text {nd }}$ International Conference of Byzantine Music and Hymnology in Athens in 2009 and by Nevin Şahin and Cenk Güray at the $2^{\text {nd }}$ International Interdisciplinary Musicological Conference of the Department of Psaltic Art and Musicology of the Volos Academy of Theological Studies in Volos in 2016.
} 
when the Ottoman Empire went through a political decline while, on the other hand, reaching an artistic climax. Among the innumerable performers and theorists, the work of two outstanding $18^{\text {th }}$ century individuals is particularly useful for musicologists who research the interaction between the Byzantine church music tradition and the Ottoman musical culture in the theorization of makam music. These theorists are Panayiotes Halaçoğlu (Chalatzoglou) and his student Kyrillos Marmarinos, both of whom belonged to Greek Orthodox clergy. The works of Halaçoğlu and Marmarinos are analyzed in comparison with the contemporary works of theorists from a variety of ethnic and religious backgrounds, and with Kiltzanidis - a 19th century theorist from the Byzantine church music tradition. The comparative study carried out between the works of these theorists and the common theoretical trends of the time periods they belong to, reveals interesting results regarding the inner relations within this multicultural texture.

\section{$1^{\text {th }}$ Century Ottoman Musical Life}

The $18^{\text {th }}$ century was a significant period in Ottoman history in that the empire, after ruling in three different continents, experienced a period of decline and strove to transform into a developed Western country, which resulted in its inevitable collapse after the World War I. According to the anti-decline scholarship, $18^{\text {th }}$ century Ottoman Empire lost its dominance and declined politically, but, on the other hand, that period witnessed the vivid daily life of modern transformation even before the official modernization effort of the state (Sajdi, 2007: 6-11). Not only did public music life flourish in İstanbul (Greve, 2017: 35-39), but also the interactions between people from different ethnic and religious backgrounds dominated the daily life. The interaction between minorities and the Turkish Muslim community was at such a level that the Islamic court ( $k a d l$ ) would deal with disputes between members of the Jewish, Armenian and Greek Orthodox communities, as well as the cases of the majority (Göçek, 2005).

Besides the royal school of the Ottoman court, Enderûn, the military, and the dervish lodges were important centers where makam music was taught and practiced by that time (Tanrikorur, 2005: 22-32). Furthermore, the Ecumenical Patriarchate cultivated theoretical contributions on makam music by the performers of ecclesiastical music within (Güray \& Aydın, 2011). This also reflected the rising 
interest in secular music, which was nourished by the humanist education of higher classes (Popescu-Judetz \& Sirli, 2000: 10).

The ethnic diversity of the city contributed to the colorful daily life, frequently enjoyed in tulip gardens and coffee houses, with a variety of spatial identifications and music circles. Fener district, for instance, was the location of mainly Greek neighbors and the Phanariots, who were of higher socio-economic status and cultural elitism, played an active role in the music scene of the city. They were musicophiles; they not only enjoyed reading music, which led to the proliferation of manuscripts, especially in the $19^{\text {th }}$ century, but they also composed music, which resulted in the peculiar genre of Phanariot Songs (Kalaitzidis, 2012: 158-159).

However, it was not only Phanariots who contributed to the music scene of İstanbul in the $18^{\text {th }}$ century. Besides the Turkish composers, Greek and Armenian composers also contributed to the compilation of İstanbul-themed songs, which reflected the daily entertainment programs which took place in tulip gardens, mansions, coffee houses, and tourist sites, together with a strong affective attachment to the city (Sancar, 2003: 279-286).

This colorful daily life of $18^{\text {th }}$ century İstanbul filled with music was also supported by the Ottoman court. Some of the Ottoman sultans were themselves musicians, and they supported composers and performers by offering royal accommodation and employment in addition to commissioning compositions and manuscripts. Sultan Selim the $3^{\text {rd }}$, for instance, was an instrumentalist, who studied tanbur with the most prominent tanbur players of the time. He was also a devotee of the Mevlevi order, for which he himself composed an ayin (a genre of religious music that accompanies the whirling rituals) in the makam Suzidilara, which was, again, compounded by himself. He invited significant Mevlevi composers to the court, commissioned compositions and performances, and made them write theory books. The Mevlevi dervish Nâsır Abdülbâkî Dede authored a theory book and composed a notation system upon the order of Sultan Selim the $3^{\text {rd }}$ (Özcan, 2009: 425-426).

This period was also significant in terms of the theoretical works on makam music. Different from the previous centuries, when makam music was analyzed on a scalebased approach upon cycles (edvar), the $18^{\text {th }}$ century was characterized with a 
theoretical approach, which favors frets and intonations over cycles. The late ethnomusicologist and art historian Eugenia Popescu-Judetz (2010: 7-8) regards this change in the theoretical orientation of makam analysis as a change from a taxonomic model to a transformative model. The pioneer of the transformative model was, surprisingly, not a theorist raised within the taxonomic model, but rather a multicultural outsider, the Moldavian prince Dimitri Cantemir, in the early $18^{\text {th }}$ century. Popescu-Judetz called his theoretical understanding "an analytic and even a constructivist approach" (Güray \& Aydın, 2011).

\section{The Contribution of Greek Orthodox Theorists to Makam Theory}

In light of the general view of the $18^{\text {th }}$ century music life of the Ottoman Empire, the works of Halaçoğlu and Marmarinos can be evaluated through comparative analysis. Before digging into the cultural reflections on theory, it should be emphasized that both theorists were raised in a multicultural environment.

With roots going back to Trabzon, Panayiotes Halaçoğlu was the protopsaltes of the Ecumenical Patriarchate. After receiving his education on Byzantine chant on Mount

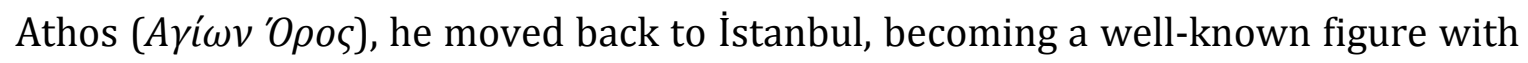
a mission in the patriarchate and a position in the music school of the patriarchate in Fener district. His work comparing makams and Byzantine modes (echoi) is the first ever comparative study in makam theory (Popescu-Judetz \& Sirli, 2000: 12-15).

Yet another comparative study is the work of Kyrillos Marmarinos, who was a student of Halaçoğlu. A clergyman like his teacher, Marmarinos was also a multicultural composer with liturgical compositions in genres such as sticherarikon and kalophonikoi heirmoi and compositions in makam music in genres such as semai. His treatise, titled Eisagogi Mousikis (Introduction to Music), written approximately 20 years after Halaçoğlu's treatise, devotes its third chapter to a similar comparison of makams and Byzantine modes made by his teacher (Popescu-Judetz \& Sirli, 2000: 16-18).

The influence of Cantemir on Halaçoğlu's work is undeniable, which he acknowledges at the very beginning. In an understanding similar to Cantemir, Halaçoğlu analyzes makams on a fret-based approach rather than a cycle-based approach. His student Marmarinos also takes this stance, but a slight difference 
occurs in their comparison of basic makams (kyria makamia) and basic modes (kyria echoi), as shown in Table 1. This difference might have resulted from the fact that Marmarinos was also a performer, who worked together with Turkish masters (Popescu-Judetz \& Sirli, 2000: 87).

\begin{tabular}{|l|l|l|}
\hline Frets & $\begin{array}{l}\text { Correspondent Echoi } \\
\text { in Halaçoğlu }\end{array}$ & $\begin{array}{l}\text { Correspondent Echoi } \\
\text { in Marmarinos }\end{array}$ \\
\hline Yegâh & Aneones & Plagal I heptaphonos \\
\hline Aşîran & Neeanes & Plagal II \\
\hline Irak & Barys aanes & Barys \\
\hline Rast & Neagie & Plagal IV \\
\hline Dügâh & Ana(nea)nes & Authentic I \\
\hline Segâh & Neanes & Authentic II legetos \\
\hline Çargâh & Nara & Authentic III \\
\hline Nevâ & Hagia & Authentic IV \\
\hline Hüseynî & Plagal I & Authentic I tetraphonos \\
\hline Eviç & Plagal II & Authentic II \\
\hline Gerdaniye & Plagal barys & Authentic III \\
\hline Muhayyer & Plagal IV & Authentic IV \\
\hline
\end{tabular}

Table 1. Byzantine modes compared to basic makams on a fret-based approach in Halaçoğlu and Marmarinos.

Halaçoğlu divides the makam structures into two groups, based on the frets (basic building blocks of makam structures - sounds created by intonations addressing to an interval of frequencies). He produces 12 main makams from the main frets, and from the half frets he produces 52 'derived makam' so called şube. Neither the main makams nor the şubes have a direct relation to the $15^{\text {th }}$ century theory. Subes are further divided into two groups of 'basic' and 'irregular.' Basic şube structures can be defined in relation to one fret, but the irregular ones can only be defined through a transposition, or the interaction of different frets. In his theoretical approach, he also cares about melodic movement within the structures.

The turn of the $19^{\text {th }}$ century witnesses the important works of Kiltzanidis (Pappas, 1997; Popescu-Judetz, 2010) in the Patriarchate. Kiltzanidis, similarly to Halaçoğlu, 
classifies the organizations as makam and şube. In his work, 12 main makams are related to the 12 main frets. The main şubes are related to the half frets. The other 167 organizations, which cannot be attained with a specific fret are referred to as şube (also called/defined as irregular in the manuscript). His approach has no direct relation to the $15^{\text {th }}$ century theory either. Similarly to Halaçoğlu, Kiltzanidis also defines Ottoman music theory through Byzantine music theory.

It is interesting to note that Marmarinos' $18^{\text {th }}$ century theoretical approach is slightly different from that of the other representatives of the Patriarchate (Popescu-Judetz \& Sirli, 2000; Güray, 2012: 107). He defines 12 makams in relation to the main frets. He remarks that Old Persian masters related 7 main makams to 7 planets, resembling the relation of the avazes (structures that do not have a full scale, as is the case of makams) to planets in the $15^{\text {th }}$ century theory. He defines 19 nims in relation to the half frets. Marmarinos defines şubes as composed of a synthesis of two separate structures, parallel to the avaze and terkip (makam compound) definition of the $15^{\text {th }}$ century. Therefore, it can be argued that Marmarinos preserves the fret-based classification of Halaçoğlu which was later used by Kiltzanidis too. His main system of classification depends on the specific characteristics of frets and their relations/interactions with other frets with the classes named as makam and nim, resembling the trend led by Cantemir. But unlike Halaçoğlu and Kiltzanidis, he clearly places the organizations that occur when several structures are compounded, in another class, thus differentiating from the other two theorists - a move that recalls the theory of the $15^{\text {th }}$ century.

It should also be emphasized that both Halaçoğlu and Marmarinos hesitated to express Ottoman identifications related to makam music. While Halaçoğlu named makams as Persian, Marmarinos referred to the makam music as Arabo-persian, emphasizing the Persian and Middle Eastern ethnic connotations rather than Ottoman, Turkish and Anatolian connotations. This has to do with the tradition being merely named musiki in the Ottoman Empire without any ethnic identifications (Popescu-Judetz \& Sirli, 2000: 9-12) but it might also be related to the geographical intersection between the Byzantine Empire and the Ottoman Empire, thus an effort to consolidate the Byzantine and Greek Orthodox identity by avoiding any Ottoman references. Similarly, the $19^{\text {th }}$ century manuscript on Byzantine 
notation by Apostolos Constas refers to makam music as dış musiki (external music) (Pappas \& Beşiroğlu, 2007: 35) in an effort to distinguish the Byzantine musical identity from the Ottoman musical identity.

A closer look into Marmarinos's work also reveals connections with the multicultural structure of the Ottoman Empire. His reference to the $15^{\text {th }}$ century cycle-based theory not only differentiates his work from other Greek Orthodox theorists but it also relates to the works of Nâsır Abdülbâkî Dede, who makes constant comparisons between kudemâ (predecessors) and müteahhirîn (successors) (Tura, 2006) in terms of theory transmission throughout the centuries, and Tanburî Küçük Artin, who has a broader geographical understanding of makam and refers to Persian as well as Indian traditions together with the Ottoman understanding (Popescu-Judetz, 2002).

It must also be noted that both Marmarinos and Nâsır Abdülbâkî Dede reference the debates concerning music theory. Marmarinos says that the masters whom he consulted, participated in large disputes with each other, and thus he decided to take what was sound and reasonable to him into his theory (Popescu-Judetz \& Sirli, 2000: 87). Abdülbâkî Dede starts his discussion as early as Pythagoras and states that the ancients and the moderns have differing, and from time to time nonsensical, ideas concerning makams; he concludes his preface by saying that his theory is a response to such nonsense (Tura, 2006: 29-32). Despite the influence of the transformative model initiated by Cantemir on both Marmarinos's and Abdülbaki Dede's works, the two treatises have an important difference in that the influence of Sultan Selim the $3^{\text {rd }}$ in Abdülbâkî Dede's work cannot be denied. This influence has to do with the innovative approaches towards modernity on the state level, which dominated the reforms of the $19^{\text {th }}$ century and resulted in the sultan commissioning Abdülbâkî Dede to compose his theoretical treatise. 


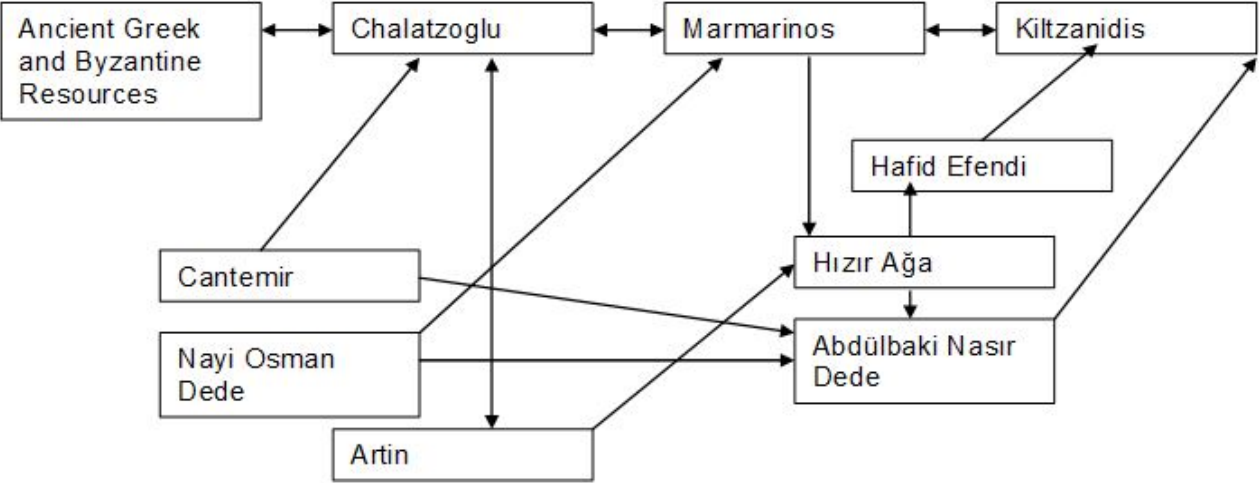

Table 2. Interaction between theorists of $18^{\text {th }}$ and $19^{\text {th }}$ centuries (Güray, 2012: 108).

The similarities in the interpretations of makam theory reveal that neither the Greek Orthodox theorists, nor the Turkish Muslim theorists remained limited to their local theoretical understandings, but rather benefitted from each other's contribution to makam theory. The dynamism of makam theory can be further traced to the $19^{\text {th }}$ and $20^{\text {th }}$ centuries. The move from the taxonomic model to the transformative model in the $18^{\text {th }}$ century, for instance, at one point encounters modernization and Westernization, leading to the makams being explained using the terminology of Western art music, as is the case with the 19th century theorist Haşim Bey (Yalçın, 2016). It can be argued that sociopolitical processes of modernization and nationstate formation also played role in the transformation of makam theory throughout the $18^{\text {th }}$ and $19^{\text {th }}$ centuries. However, a meticulous look into the music is crucial in seeing sociological connections. Analyses of the notations and recordings might tell a musical story of the dynamic history of makam theory beyond the interaction of Greek Orthodox and Turkish Muslim theorists, especially for the $19^{\text {th }}$ century.

\section{Conclusion}

The practical characteristics of the treatises by the Greek Orthodox theorists reveal that they were developed from a complex combination of resources, and carried a strong trace of the Byzantine church tradition, while at the same time, in practice, extensively interacting with the makam tradition of the Ottoman musical culture. 
These treatises also reflect the rich heritage of Greek Orthodox composers within the Ottoman tradition. On the socio-cultural level, the treatises show a strong connection to the Greek Orthodox identity, constructing bonds with the Byzantine music theory. This stance also strengthens the identity by differentiating the Greek Orthodox musical culture from the Ottoman, based on the initiative of the interaction of Ottoman music with the Arabic and Persian musical cultures. This identification is enhanced throughout centuries together with the rise of nationalistic ideologies (Erol, 2015). However, this cultural identification of music theory does not stand as a paradox since the music theory transmits not only the musical choices but also the social cross-sections covering the musical representation.

Besides the cultural significance of the works of Greek Orthodox theorists, Marmarinos's work is special in terms of having a vision of combining the new theoretical trends of the $18^{\text {th }}$ century with the classical theory of the $15^{\text {th }}$ century. Hence, these three theorists who were raised in the same environment, contributed to different topics of Ottoman musical theory after the $17^{\text {th }}$ century. Halaçoğlu and Kiltzanidis, efficiently transmitted and improved the fret- and melodic directionbased classification approach led by Cantemir. They also transmitted Byzantine musical theory, in combination with Ottoman musical theory to the $20^{\text {th }}$ century. On the other hand, Marmarinos, as an additional contribution to Halaçoğlu and even Kiltzanidis, became one of the last theorists to have carried visible traces of the $15^{\text {th }}$ century theory into the $20^{\text {th }}$ century, in a period when the traces of this ancient theory were nearly lost due to the severe effects of Westernization (Öztürk, 2018: 1777-1778). The detailed analysis of the old musical sources which exist within the borders of the Ecumenical Patriarchate, will deeply assist the researchers to further enlighten the critical effects of the Greek Orthodox theorists in the construction, variation and transmission of the Ottoman Music Theory. 


\section{REFERENCES}

Erol, Merih. (2015). Greek Orthodox Music in Ottoman Istanbul: Nation and Community in the Era of Reform. Bloomington: Indiana University Press.

Greve, Martin. (2017). Makamsiz: Individualization of Traditional Music on the Eve of Kemalist Turkey. Würzburg: Erlon Verlag.

Göçek, Fatma Müge (2005). "The Legal Recourse of Minorities in History: Eighteenth-century Appeals to the Islamic Court of Galata" Minorities in the Ottoman Empire. Ed. Molly Greene: pp. 47-70. Princeton: Markus Wiener Publishers.

Güray, Cenk. (2012). Bin Yılın Mirası-Makamı Var Eden Döngü: Edvar Geleneği. [The Legacy of Millennium-The Cycle That Created Makam: Edvar Tradition] İstanbul: Pan Publishing.

Güray, Cenk and Aydın, Ali Fuat. (2011). The Effects of the Theorists of the Ecumenical Patriarchate to the Ottoman Musical Theory after the XVII. Century: Similarities and Differences. Paper presented at the $3^{\text {rd }}$ International Conference of Byzantine Music and Hymnology. Athens, Greece, 29 October-2 November.

Kalaitzidis, Kyriakos. (2012). Post-Byzantine Music Manuscripts as a Source for Oriental Secular Music (15 th to Early 19th Century). Würzburg: Erlon Verlag.

Özcan, Nuri. (2009). “Selim III, Musiki” [Selim III, Music] İslam Ansiklopedisi. 36: 425426. Ankara: Türkiye Diyanet Vakfı Publishing.

Öztürk, Okan Murat. (2018). "How was the traditional makam theory westernized for the sake of modernization?" Rast Musicology Journal. 6 (1): 1769-1787.

Pappas, Miltiadis. (1997). “Kiltzanidis'in Kitabı” [Kiltzanidis’s Book] Master's Thesis. İstanbul Technical University, İstanbul: Turkey.

Pappas, Miltiadis and Beşiroğlu, Ş. Şehvar. (2007). “Apostolos Konstas'ın Nazariyat Kitabı'na ilişkin bir inceleme"[A research on the Theory Book of Apostolos Konstas] İTÜ Dergisi/B. 4(2): 33-42. 
Popescu-Judetz, Eugenia. (2010). Three Comparative Essays on Turkish Music. İstanbul: Pan Publishing.

Popescu-Judetz, Eugenia. (2002). Tanburî Küçük Artin: A Musical Treatise of the Eighteenth Century. İstanbul: Pan Publishing.

Popescu-Judetz, Eugenia; Sirli, Adriana Ababi. (2000). Sources of 18 th Century Music: Panayiotes Chalatzoglou and Kyrillos Marmarinos' Comparative Treatises on Secular Music. İstanbul: Pan Publishing.

Sajdi, Dana (Ed.) (2007). Ottoman Tulips, Ottoman Coffee: Leisure and Lifestyle in the Eighteenth Century. London \& New York: I. B. Tauris.

Sancar, Fahriye Hazer. (2003). "City, Music and Place Attachment: Beloved İstanbul" Journal of Urban Design. 8 (3): 269-291.

Tanrıkorur, Cinuçen. (2005). Osmanlı Dönemi Türk Musikisi. [Turkish Music in the Ottoman Era] İstanbul: Dergâh Publishing.

Tura, Yalçın. (2006). Nâsır Abdülbâkî Dede, Tedkîk ü Tahkîk. İstanbul: Pan Publishing. Yalçın, Gökhan. (2016). 19. Yüzyıl Türk Musikisinde Hâşim Bey Mecmuası: Birinci Bölüm Edvâr. [Haşim Bey's Manuscript in the 19th Century Turkish Music: First Chapter Edvar] Ankara: Atatürk Kültür Merkezi Başkanlığı Publishing 